\title{
САРАБДАЛ САҒЫНТАЙДЫ САҒЫНҒАНДАҒЫ СУСЫҒАН СЫРЛАР...
}

\author{
(C) 2019 ж. Ғ.Қ. Омаров
}

Еске алу мақаласы өмірден ерте кеткен археолог-Сағынтай Сұңғатайға арналған. С. Сұңғатайдың ата-бабалары 90 жылдан астам бұрын ШҚО Марқакөл ауданынан тағдыр тәлкегімен Қытайға ауған. Жылдар өте келе Шыңжаң университетінде археология мамандығы бойынша білім алып (1989 ж.), Үрімші қаласындағы Археология институтында бірнеше жыл жұмыс істеп (1989-1994 жж.) Сағынтай тарихи атамекеніне оралуға шешім қабылдайды. Осы жолдардың авторы еліміздің шығысындағы әртүрлі экспедицияларда бірге болған сол бір күндерін ыстық сағынышпен еске алады. С. Сұңғатай - тек қана археология ғана емес, сондай-ақ әдебиет, философия, музыкамен айналысқан, өмірде болып жатқан жаңалықтардан сырт қалмаған сан қырлы тұлға.

Түйін сөздер: археология, С. Сұңғатай, Шығыс Қазақстан, археолог

...Сағыныш тегі ар-намыс, Сағынған жанның зары ерен.

Ермұрат Зейіпхан

Адам өмірінің тым қысқа екендігін кеше ғана қасыңда жүрген іні-дос, әріптес жанның бір-ақ күнде жоқ болғанында ғана біледі екенсің. Іштей егіле солбір бірге жүрген күндердің керемет сәттерін сағынышпен көз алдыдан өткізе отырып елжірей еске аласың. Шынында да ойладық па, Сақаңнан осындай тез айырылып қаламыз деп. Сыр бүккен қара нөпір ішкі ойының ақтарылмаған талай тұмса тың туындыларын өзімен бірге ала кетті. Амал нешік...

Қайтыс болған адамның соңынан естелік жазу оңай шаруа емес, қиынның қиыны. Ол оның үстіне ең бір етжақын көретін жақын жаның болса. Дегенмен мен алғашқы танысқан күндерден бастап есте қалаған кейбір мөлтек сәттерді еске түсіруге тырысайын.

Сағынтаймен алғашқы танысуым 1996 жылы болуы керек, Ә.Х. Марғұлан атындағы Археология институтына жолым түсіп бара қалсам Зекең (Зайнолла Самашев): «Әй, Ғани, мына туысыңмен таныс» - деп мен бұрын көрмеген көзіне көзілдірік таққан, өзім сияқты «кіркөтерімді» жігітті нұсқады. Таныстықтан кейін қандай «туысым» болды екен деп жөн сұрассам, Қытайдан келгендігін, елінің - Найман екендігін айтты. Мен де «оның ішінде қайсысың?» - деп бастырмалатып жатырмын. Қойшы, сонымен екеуімізге де ортақ Қожамбет 
Омаров Ғ.К. Сарабдал Сағынтайды сағынғандағы сусыған сырлар...

атамызға барғанда құшақтай алыппын. Жалпы арғы аталарының мен өскен Марқакөл жерінен аттай 90 жылдай бұрын кеткендіктерін айта келе, онда туысқандары тұратындығын, елге бару арманы екенін де еш бүкпесіз айтып өтті. Өстіп сол күннен бастап қамшының қос өріміндей ағалы-інілік, достық, әріптестік ғұмырымыз басталды. Сонан кейін ара-тұра кездесіп тұрғанымызбен, шынайы бірбірімізді жақыннан тануымыз 1997 жылы 3. Самашевтың басқаруындағы Қазақ-француз-итальян біріккен Шығыс Қазақстан халықаралық археологиялық экспедициясында болды. Сол экспедицияға сайдың тасындай бір-бірінен өтетін азаматтар жиналған еді. Дала археологиясының «қара нары» - Жұмаш Жетібаев, қазба жұмысының нағыз майталманы - Дәулет Қожақов, қандай жұмысқа салсаң да мыңқ етпейтін, «орыс» мінезді - Ойрат Ишманов, ата жұртқа Мұңғылиядан оралған этнограф Досымбек Қатыран, Қытайдан келген археолог - Сағынтай Сұңғатай және осы жолдардың авторы бір шатырға жайғастық. Кешке қарай жұмыстан соң тек қана археология ғылымы ғана емес, тарих, әдебиет, өнер туралы пікір таластырамыз. Сол кезде бір байқағаным Сағынтайдың аталған салалар бойынша 1989 жылы Шынжаң университетінің Тарих факультетін бітіргендігі білімі, 1989-1994 жылдары Үрімші қаласындағы Шынжаң Археология ғылыми зерттеу институтында ғылыми қызметкер болып жүрген уақытта халық арасында көп болғаны, сондай-ақ көп оқығандығы болар кез-келген тақырыпта айтар өз ойы, ұстанымы болатын. Дәл осы жерде айта кетейін, Университеттегі дипломдық

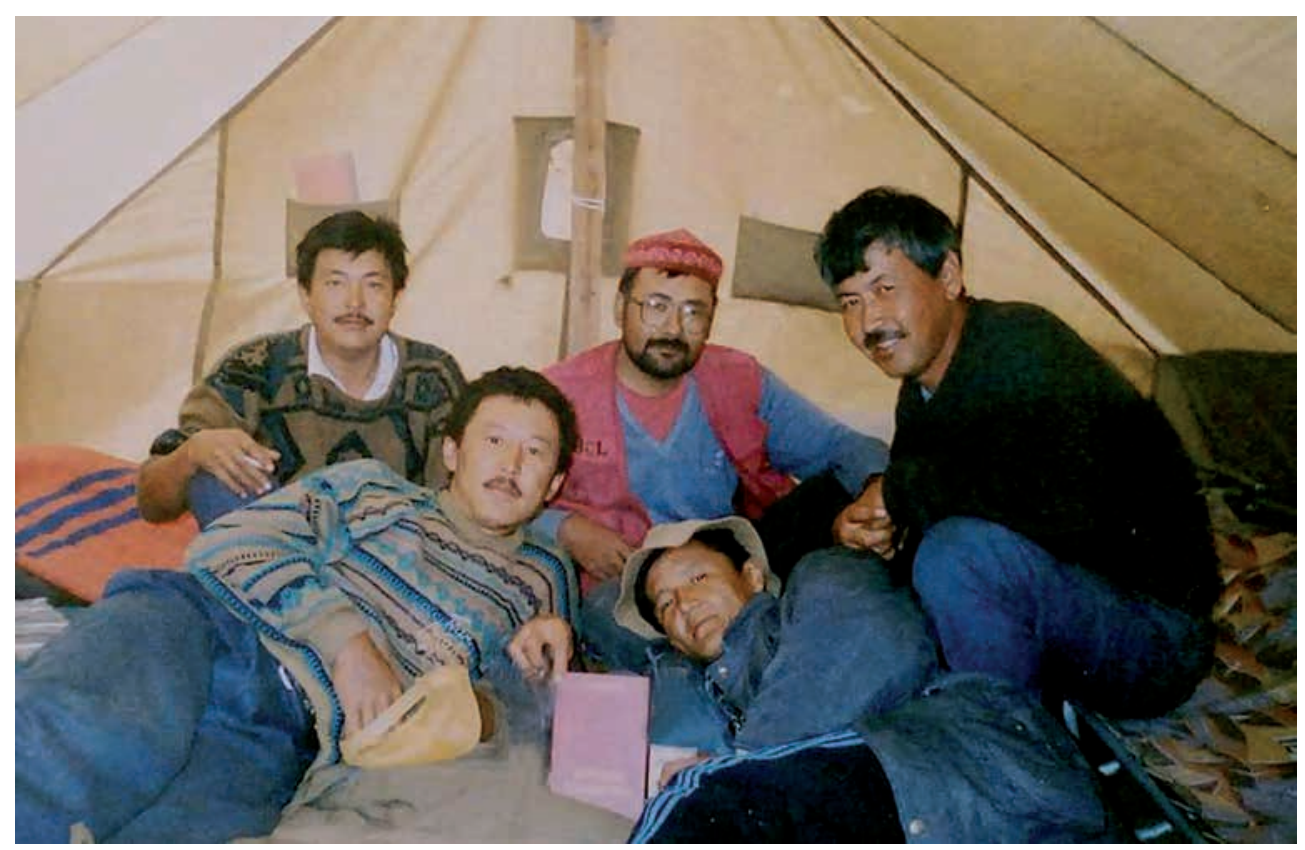

Майемердегі экспедицияда, 1997 ж. Солдан оңъа қุарай: Ғ. Омаров, Д. Қатыран, С. Сұнъатай, Д. Қожақ̆ов және Ж. Жетібаев. Фото Ю.Ф. Черкаминдікі In the expedition. Mayemer, 1997. From left to right: G. Omarov, D. Katyran, S. Sungatay, D. Kojakov, J. Jetibayev. Photo by Yu. Cherkashin 
жұмысы негізінде жазылған «Несториан дінінің тарихта қазақтар арасында таралуы» атты ғылыми мақаласына 1994 жылы ШҰАР қоғамдық ғылымдар академиясы тарапынан «Қоғамдық ғылымдар бойынша II дәрежелі таңдаулы ғылыми мақала» деп танылып, жеңімпаз болса, сол мақала ерекше қызығушылық туғызғандықтан 2001 жылы Қытайдың «Синьцзян вэнь-у» журналы әдейілеп аударып басқан екен.

1997 жылы Шығыс Қазақстанның Майемер ауылындағы Қазақ-француз-итальян біріккен халықаралық археологиялық экспедициясына барған кезде Алтай тауының шалғай бір қуысында күнделікті оқитын газет, журнал атаулы жоқ. Шағын радиодан ғана хабар бар ма деп қоссақ
Қазақстандық толқынның ешқайсысы алмайды. Өзінің Қытайдан әкелген кішкене радиосын алып бір жотаға - Сағынтай, екінші жотаға - Досымбек кетеді. Біз қалғанымыз күнделікті жаңалықтарды Қытай мен Мұңғылияның радио толқындары арқылы білеміз. Сағынтайды «Қытайдың», ал Досымбекті «Мұңғылияның шпионы» - деп қалжыңдай келе, ақыры екеуіне құлақ тосамыз. Сақаң қай уақытта да газетті үзбей оқыды, өмірде өтіп жатқан жаңалықтардан ешқашан сырт қалмады.

Сағынтай, әсіресе, әдебиетке жақын еді. Тіпті әдебиет майданына түскен уақыты да болды. «Ақжол Қазақстан» газетінің 2004 жылғы № 1 номерінде «Біздің «қытайтанушылар» ғылымды неге былғайды? Немесе қазақ әдебиеті тарихына еніп кеткен

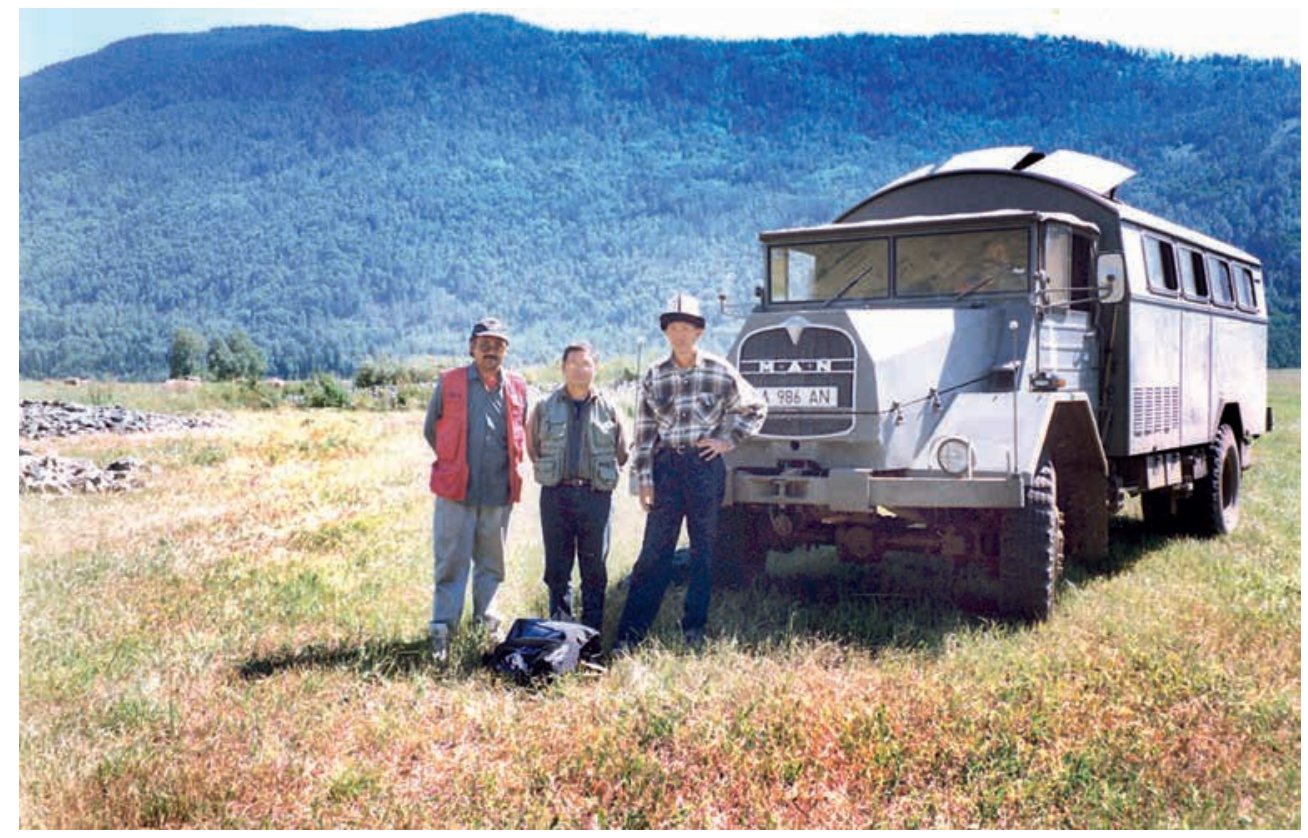

Берел, 1998. Солдан оңъва қ̧арай: С. Сұңъатай, 3. Самамев, Ж. Құрманқұлов. Фото Ю.Ф. Черкашиндікі (?)

Berel, 1998. From left to right: S. Sungatay, Z. Samashev, Zh. Kurmankulov. Photo by Yu. Cherkashin (?) 
жалған ақын туралы бірер сөз» атты мақаласында Сағынтайдың тілімен айтсақ «... исі түрік тарихында болмаған, Қытай ғалымдары саясат үшін ойлап тапқан» Кегменер Үлгеұлы деген қолдан жасалған ақынды еліміздің филологтары антологияға енгізіп жібергеніне қатты күйініп Әбдімәлік Нысанбаев, Дүкен Мәсімхан, Мұхтархан Оразбай сынды «пәлсапа және әдебиетшілерді» дәйекті фактілерді келтіре келе мақтамен бауыздаған еді. Сағынтайдың әдебиетке байланысты мақалаларының бұл бір парасы ғана.

Сағынтайдың ерекше қабілетінің арқасы болар, орыс тілінде таза сөйлей алмаса да, орыс тілінен қазақ тіліне жетік аударуды тез арада меңгеріп алды. Кейбір сөздердің адам таппайтын аудармасын, не баламасын орынды әрі төбесінен түскендей дәл таба қоятын. Сондай еңбектерінің ішіндегі ғылыми аударманың нағыз үлгісіндей 2002 жылғы И.Н. Тасмағамбетовтың «Құлпытас» атты иллюстрациялы альбом-кітабы және 2005 жылы 3. Самашев, Ф. Григорьев, Г. Жұмабековалардың «Древности Алматы» атты кітаптарын орысшадан қазақшаға аударды. Кейінгі уақыттарда «Көрші» дейтін журналға Қытай мәдениетіне қатысты мақалаларды қытайшадан қазақшаға аударуға да ат салысты. Бұл мен білетін аударма ісіндегі жұмыстарының бір парасы ғана, білмейтінім қаншама?!

Сақаңның музыкаға жақындығын да сол бір Майемер даласында жүргенде алғаш байқаған едім. Француздармен біріккен экспедицияда соларға арнап аудандық әкімшілік арнайы іс-шара өткізді. Большенарым аудандық мәдениет үйінің әртістері концерт қойды. Қонақкәде ретінде Сағынтай қазақ әндерімен бірге қытайша (ұмытпасам) «Қызыл гаулен» атты әнді гитарада орындады. Оның жақсы көретін әндерінің қатарында «Ғалия» әнімен бірге досы марқұм Ермұрат Зейіпханның «Мен жүрген жайлаудың биігі» атты әндерін сезімге берілген сәттерінде ерекше шабытпен шырқайтын. Ермұратты жақсы көрді. Ермұрат та реті келгенде әндерін халық алдына ұсынбас бұрын Сағынтайға тыңдатып алып, оның пікіріне әрдайым құлақ асып отыратындығын, Сақаң досын сағына отырып бірнеше рет айтып еді. Оның дәлелі Ермұраттың Сағынтайға арнап жазған өлеңі «Дүние ғапыл» атты жинағында жарық көрген. Амал нешік... Екеуі де жоқ.

Туған жерге, ата жұртына деген махаббаты да шексіз болатын. 2007 жылы шілдеде алдын-ала уағдаластықпен Үрімші жаққа баратын болып, мен Шілікті археологиялық экспедициясында жүргенде сонда келді. Екеуіміз Майқапшағай кеденінен өтіп, алдымен Алтай қаласына, сонан соң Фукаң қаласына бірге бардық. Сонда жүргенде Үш Боғда тауына барар жолда Сянгу ауылынан асып Угар сайының Сянгу өзеніне қосылатын жеріне дейін барып, одан қайта құлдилай келе Шұбарсай аузына дейін жаяу жүре отырып келген сәттерімізде ол өзінің оқыған мектебін, ата-бабаларының мәңгілік мекенін сондай бір сүйіспешілікпен айтқаны бар еді. Ол жердің тарихына қатысты жазған алғашқы мақалаларының бірінің жай-жапсарынан сол жолы мағлұмат алып едім. Сол жердегі ағайындардың тарихы мен этнографиясына да өзіндік зерттеу жұмыстарын жүргізумен қатар, 
Қазақстанның Марқакөл, Күршім өңіріндегі туған-туыстарын тауып алып, олармен тығыз қарымқатынас орнатты. Оны мен 1999 жылы Ресей-Қазақстан біріккен археологиялық экспедициясында және менің ғылыми жобам бойынша 2012 жылы археологиялық зерттеу жұмыстарын жүргізген сәттерімде анық көз жеткіздім. Шежіре бойынша көрмеген туысқандарын да тап басып айта алатын.

Сағынтаймен 2011 жылдың тамызында Шыңжаңдағы археологиялық ескерткіштермен танысу мақсатында біраз күн бірге болдық. Алтай, Қаба (ондағы Доғаты сынды ескерткіштер), Шеміршек, Тұрфан жеріндегі небір ескерткіштерді көрсетіп, Үрімшідегі Археология музейіндегі жәдігерлермен таныстырды. Ондағы материалдарды мықты білетіндігін, мен Қазақстанда жүргенде-ақ байқағанмын. Үрімшіде оқыған кезіндегі ұстазы, әріптесі үш бірдей археологиялық мәдениетті ашқан Лу Енгомен сол жолы Тұрфандағы музейде таныстырып еді. Ол да Сағынтайды көргенде қатты қуанып, іздеп келгеніне туған бауырын көргендей болып бір жасап қалды.

Жалпы Сағынтайдың ұстаздары мен аға-бауырларына деген сыйластығы мен ізгілік ниеті ерекше еді. Оған тарихи Отанына келгенде археологияда нағыз мықты адамдар жолықты. Ежелгі үйсіндер тақырыбын берген Алматыдағы алғашқы жетекшісі-Кемал Ақышұлы Ақышев болса, онан кейінгі жетекшісі - Карл Молдахметұлы Байпақов болды. Үрімшідегі студент күндерінен бастап өмірінің соңғы сағаттарына дейінгі ұстазы, әрі рухани ағасы - Нәбижан Мұхаметханұлы болды. Осындай атпал азаматтармен қатар ол Алматыға келгеннен кейін Бекмұханбет Нұрмұханбетұлы, Зайнолла Самашев, Нұрсан Әлімбайұлы ағаларының экспедицияларында, мекемелерінде болып, олардың тәлім-тәрбиесін алды. Сонымен қатар Бақыт Еженханұлы, Арман Зияденұлы Бейсенов, Жұмаш Мұқашұлы Жетібаев, Нәпіл Базылханұлы, Досымбек Қатыран, Нұржан Қуантайұлы сынды қатарлас аға, достарымен бірге жүрді. Археология, тарих, әдебиет саласына қатысты өз ой-толғамдарымен бөлісіп, пікір алысты. Қайтейік, жаман ауру жабысып, алдына қойған мақсаттарының орындалуы iске аспай қалды. Тек қана артында қалған ғылыми еңбектерін жинап, жинақ болып жарияланатындығына шүкіршілік етеміз.

$$
\text { Сағынтай бауырымыздың }
$$

жатқан жері жәннәтта, орны жұмақта, топырағы торқа болсын.

\section{Список основных публикаций С. Сунгатая*}

Участие в книгах, альбомах:

1. Берел. Алматы: Общественный фонд «Берел», 2000. 56 с. (в coaвm. c Самамевым 3., Базарбаевой Г., Джумабековой Г.).

2. Қазақстан тарихы туралы қытай деректемелері. I т. Саяхатнамалар мен тарихи географиялық еңбектерден таңдамалылар. Алматы: «Дайк-Пресс», 2005. 396 б. (Еженханұль Б., Ошан Ж. мен бірге).

3. Қазақстан тарихы туралы қытай деректемелері. ІІ т. Тарихи-мәдени жәдігерлер. Алматы: Дайк-Пресс, 2005. 80 б. + 132 бет жапсырма (Еженханұлы Б. мен бірге). 
Омаров Ғ.K. Сарабдал Сағынтайды сағынғандағы сусыған сырлар...

4. Исследования археологических памятников раннего периода бронзового века в Восточном Казахстане (1998-2000 годы) // Древнейшие европейцы в сердце Азии: чемурчекский культурный феномен. Ч. 1. Результаты исследований в Восточном Казахстане, на севере и юге Монгольского Алтая. / Сост. и научн. ред. А.А. Ковалев. СПб.: Изд-во ЛЕМА, 2014. С. 9-151 (в соавт. с Ковалевым А.А., Самашевым 3.).

\section{Статьи, изданные в Казахстане:}

1. Түрік қағанының кесенесі табылды // Қазақ тарихы. 1995. № 6. 5-б.

2. Несториан дінінің ортағасырлық қазақ тайпалары арасында таралуы // Қазақ тарихы. 1996. № 1. 14-18-бб.

3. Ежелгі Үйсін ұлысы - қазақ мемлекеттілігінің қайнар бастауы // Қазақ тарихы. 1997. № 1. 17-20-бб.

4. Исследование культуры древних кочевников Казахстанского Алтая // Проблемы изучения и сохранения исторического наследия. Алматы: КазНУ им. аль-Фараби, 1998. С. 174-202 (в соавт. с Самашевым 3.С., Франкфортом А.-П., Ермолаевой А.С., Джумабековой Г., Гий Э., Жетибаевым Ж., Омаровым Г.).

5. Ежелгі берелдіктердің ғажайып мәдениеті // Қазақ тарихы. 1999. № 2. 57-65бб. (в соавт. с Самашевым 3., Жұмабековой Г.).

6. Қазақ Алтайының скиф-сақ дәуіріндегі мәдениеті // Отан тарихы. 1999. № 4. 60-70-бб. (в соавт. с Самамевым 3., Жұмабековой Г., Базарбаевой F.).

7. Алтайдағы Берел обалары// Абай. 2000. № 1. 6-10-бб. (в соавт. с Самашевым 3., Жұмабековой Г.).

8. Көне түркілердің алтын маскасы // Известия НАН РК. Сер. обществ. наук. 2001. № 5. (234). C. 16-19.

\section{Зарубежные публикации:}

1. Христиан дінінің тарихта қазақтар арасына таралуы // Синьцзян қоғамдық ғылымы. 1991. № 1.

2. Қазақ даласының ежелгі археологиялық мәдениеті туралы // Синьцзян қоғамдық ғылымы. 1992. № 2. 1992. № 1.

3. Санжы өңіріндегі кейбір тарихи-мәдени ескерткіштер // Үйрену және ғылым.

4. Фукаң ауданынан табылған қарақытай қола айнасы қола дәуірінің тас кетпені және тас шар // Синьцзян қоғамдық ғылымы. 1993. № 3.

5. Фукан сянь фасянь силяо тунцзин чинтун шидаи шичу цзи шицю // Синьцзян ван-у. 1993. № 1.

6. Фукан фасянь силяо тунцзин // Чжунго вэн-у бао. 1993.04.25.

7. Іленің жоғарғы аңғарындағы ежелгі усундердің археологиялық мәдениеті // Синьцзян қоғамдық ғылымы. 1995. № 1.

8. Қазақ даласы петроглифтеріндегі бақсы-абыздар бейнесі // Синьцзян қоғамдық ғылымы. 1996. № 1 (в соавт. с Самашевым 3., Франкфортом А.-П., Жетібаевым Ж.).

9. Новые исследования на могильнике Берель в Восточном Казахстане // Итоги изучения скифской эпохи Алтая и сопредельных территорий. Барнаул: АлтГУ, 1999. С. 159-164. (в соавт. с Самамевым 3., Джумабековой Г.).

10. Қазақстан Алтайындағы ежелгі көшпелілердің тыңынан ашылған археологиялық ескерткіштері // Синьцзян қоғамдық ғылымы. 1999. № 2 (в coaвm. с Самамевым 3., Жұмабековой Г.).

\section{Переводческая деятельность:}

1. Жұптасқан құс мүсінді қанжарлардың Солтүстік Қытай мәдени аймағына таралуы. Перевод статьи Ян Цзяньхуа с кит. на каз. яз. // Кадырбаевские чтения-2010: сб. матер. II междунар. научн. конф. / Научн. ред. А.А. Бисембаев. Актобе, 2010. С. 106-108. Оригинал статьи на кит. яз. на с. 108-112. 
*Список публикаций С. Сунгатая составлен Г.А. Базарбаевой и Г.С. Джумабековой на основе данных из личного дела аспиранта С. Сунгатая из фондов архива Института археологии им. А.Х. Маргулана. Благодарим Ж. Ошан за уточнения по публикациям Института востоковедения им. Р.Б. Сулейменова.

\section{Автор туралы мәліметтер:}

Омаров Ғани Қалиханұлы - тарих ғылымдарының кандидаты, Археология, этнология және музеология кафедрасының меңгерушісі, әл-Фараби атындағы Қазақ ұлттық университеті (Алматы қ., Қазақстан); gani.omarov@kaznu.kz

\section{Памяти С. Сунгатая (1967-2019)}

\section{Г.К. Омаров}

Воспоминание посвящено безвременно ушедшему из жизни археологу - Сагынтаю Сунгатаю. Семья С. Сунгатая более 90 лет назад вынуждена была эмигрировать в Китай с территории Маркакольского района ВКО. Спустя годы, получив образование в Синьцзянском университете по специальности археолог (1989 г.) и несколько лет проработав в НИИ в г. Урумчи (1989-1994 гг.), Сагынтай принял решение вернуться на историческую родину. Автора строк связывают с С. Сунгатаем самые теплые воспоминания о поре совместного участия в различных экспедициях на востоке нашей страны. С. Сунгатай - многогранная личность, он живо интересовался не только археологией, но и литературой, философией, музыкой. Всегда находился в курсе современной ситуации.

Ключевые слова: археология, С. Сунгатай, Восточный Казахстан, археолог

\section{In memory of S. Sungatay (1967-2019)}

\section{G.K. Omarov}

The memory is dedicated to the archeologist Sagyntay Sungatay. The family of S. Sungatay more than 90 years ago was forced to emigrate to China from the territory of Markakol region of the East Kazakhstan. He received an education in the Xinjiang University as an archeologist (1989) and after several years he was working in a research institute in the city of Urumqi (1989-1994). Then Sagyntay decided to return to his historic homeland. The author wrote the warmest memories about S. Sungatay, their joint participation in various expeditions in the east of our country. S. Sungatay was a multifaceted personality. He was keenly interested not only in archeology, but also in literature, philosophy, and music. He was always aware of the current situation.

Keywords: archaeology, S. Sungatay, East Kazakhstan, archeologist

\section{About the Author:}

Omarov Gany K. Candidate of Historical Sciences, Head of the Department of Archeology, Ethnology and Museology, al-Farabi Kazakh National University (Almaty, Kazakhstan); gani.omarov@kaznu.kz 